\title{
Effects of an exogenous protease on the fermentation and nutritive value of corn silage harvested at different dry matter contents and ensiled for various lengths of time
}

\author{
M. C. Windle, ${ }^{*}$ N. Walker, $†$ and L. Kung Jr. ${ }^{* 1}$ \\ *Department of Animal and Food Sciences, University of Delaware, Newark 19717 \\ †AB Vista - Division of AG Agri Ltd., Marlborough, Wiltshire, SN8 4AN, United Kingdom
}

\begin{abstract}
The objective of this experiment was to evaluate the effects of adding an experimental protease to corn plants harvested at different maturities on silage fermentation and in vitro ruminal starch digestibility (IVSD). Corn plants were harvested at maturities resulting in plants with 31 or $40 \%$ dry matter (DM). Plants were chopped, kernel processed, and treated with (1) only a $0.1 \mathrm{M}$ phosphate buffer ( $\mathrm{pH} 5.5,5 \% \mathrm{vol} / \mathrm{wt}$ of fresh forage), (2) buffer with protease to obtain a final concentration of $20 \mathrm{mg}$ of protease $/ \mathrm{kg}$ of wet forage, and (3) buffer with protease to obtain a final concentration of 2,000 $\mathrm{mg}$ of protease $/ \mathrm{kg}$ of wet forage. Treated forages (about $500 \mathrm{~g}$ ) were ensiled in nylon-polyethylene pouches and stored between 21 and $23^{\circ} \mathrm{C}$ for $0,45,90$, and $150 \mathrm{~d}$. Data were analyzed as a $2 \times 3 \times 4$ factorial arrangement of treatments, with the main effects of harvest DM, dose of protease, days of ensiling, and their interactions. The treatment with the highest dose of protease resulted in more robust fermentations across harvest DM with higher concentrations of lactic and acetic acids compared with untreated silage. Concentrations of soluble protein (\% of crude protein) increased with time of ensiling, regardless of DM content at harvest. However, averaged over both harvest DM contents, it increased by $37 \%$ for silages treated with the high dose of protease compared with an average $11 \%$ increase for untreated silages and silage treated with the low dose of protease, between d 0 and 45. Averaged over both harvest DM contents, the concentration of soluble protein peaked in silages treated with the high dose of protease after $45 \mathrm{~d}$ of ensiling, whereas it peaked at d 90 in untreated silages and silage treated with the low dose of protease. Similar changes occurred in the concentration of $\mathrm{NH}_{3}-\mathrm{N}$ due to length of ensiling and treatment with protease. In fresh forages, the concentration of starch for early- and late-harvested forages
\end{abstract}

Received October 10, 2013.

Accepted January 22, 2014

${ }^{1}$ Corresponding author: lksilage@udel.edu was similar, but IVSD was lower in the latter. After 45 $\mathrm{d}$ of ensiling, IVSD was highest in both early- and lateharvested silages that were treated with the high level of protease. After $150 \mathrm{~d}$ of ensiling, IVSD was similar among silages treated with protease, regardless of DM at harvest. Treating corn plants with a high dose of an experimental protease at harvest accelerated proteolysis during ensiling, resulting in corn silages with levels of IVSD after $45 \mathrm{~d}$ of ensiling that were only obtained in untreated corn silages after $150 \mathrm{~d}$ of ensiling.

Key words: rumen, starch, protease, silage

\section{INTRODUCTION}

The optimum time for harvesting plants to make corn silage for horizontal silos occurs when the whole plant reaches a DM of about 32 to $35 \%$ (Shaver et al., 1999; Johnson et al., 2002). However, in practice, corn is often harvested when plants are lower (less mature) and higher in DM (more mature), for a variety of reasons. In some instances, harvest begins early because inadequate capacity exists to harvest large amounts of forage in a short period of time. In contrast, harvesting of mature plants often occurs because equipment often cannot keep pace with increasing plant maturity or because custom harvest equipment is not available at the optimal harvest time. Lack of monitoring wholeplant DM is also a common reason for harvest to occur outside of the recommended range of DM. The common characteristics for corn plants harvested with low DM contents are low yields of DM and starch, whereas the opposite is true for plants harvested when they are overly mature (Johnson et al., 2002). Although it would appear advantageous to harvest corn at higher concentrations of DM because of the higher yields and concentrations of starch, this material is more difficult to pack and the resulting silage often spoils rapidly when it is exposed to air (Montgomery et al., 1974). Another difference between early- and late-harvested corn plants is that in the latter, an increased complexity of the prolamin-starch matrix yields plants with relatively low ruminal starch digestibility compared 
with more immature plants (Hoffman et al., 2011). To compensate for this finding, it is suggested that mature corn plants undergo mechanical processing, which increases the amount of readily accessible starch by breaking corn kernels into small pieces (Johnson et al., 2003). The result of this practice is an improvement in ruminal starch digestibility in well- versus poorly processed corn plants (Philippeau and Michalet-Doreau, 1998; Ebling and Kung, 2004). However, even overly mature corn that is well processed is often still lower in ruminal starch digestion than corn that is harvested at optimum maturity and relatively poorly processed (Schwab et al., 2003).

Protease enzymes have the potential to make starch more available for general fermentations and digestion. For example, proteases have been used in the biofuels industry to stimulate the production of ethanol by yeasts (Vidal et al., 2009). In ruminant applications, Colombatto et al. (2003) treated feeds with enzymes containing protease activity just before ruminal in vitro digestibility experiments and reported an increase in fiber digestibility in some feeds. Eun and Beauchemin (2005) treated a pellet supplement with a protease formulation and incorporated that into TMR for lactating cows. They reported an increase in total-tract digestion of fiber and starch when cows were fed the treated feed. Using proteases as silage additives has not been studied because proteolysis has usually been considered to be undesirable during silage fermentations (Rooke and Hatfield, 2003). However, we (Young et al., 2012) recently reported that the addition of exogenous proteases to corn plants at harvest accelerated the increase in ruminal in vitro starch digestibility (IVSD) that naturally occurs with time of ensiling. Because the starch in mature corn is more difficult to digest than starch in immature corn, we hypothesized that the effectiveness of adding a protease to corn plants differing in stages of maturity may vary. Thus, the objective of the current experiment was to evaluate the effects of adding a protease enzyme to corn plants harvested at 2 maturities on the resulting silage fermentation and potential ruminal IVSD of corn silage.

\section{MATERIALS AND METHODS}

\section{Forage Preparation and Treatments}

Corn plants (Mycogen hybrid A6867; Mycogen Seeds, Indianapolis, IN) were grown at the University of Delaware (Newark) and harvested by hand from 5 random locations within a field at 2 stages of maturity: $30.69 \%$ DM (early, ER) or $40.33 \%$ DM (late, LT). The LT corn was harvested from the same field and ensiled 13 d after ER corn. Plants were chopped to a theoretical length of $19 \mathrm{~mm}$ using a pull-type chopper equipped with a kernel processer and a roller gap setting of 1.35 mm (John Deere 3975; John Deere, Moline, IL). Each of the 5 piles of chopped forage at each harvest were further divided into 3 additional piles and treated with $0.1 M$ phosphate buffer ( $\mathrm{pH} 5.5,5 \% \mathrm{vol} /$ wt of fresh forage, $\mathbf{C T}$ ), the same phosphate buffer with a protease formulation resulting in $20 \mathrm{mg}$ of protease $/ \mathrm{kg}(\mathbf{L O})$ of forage ( $\mathrm{AB}$ Vista, Wiltshire, UK), or the phosphate buffer with a protease formulation resulting in 2,000 $\mathrm{mg}$ of protease $/ \mathrm{kg}$ of wet forage $(\mathbf{H I})$. The protease was a preparation from Aspergillus niger with a low $\mathrm{pH}$ (3) optimum for activity and was the same preparation (E85 formulation) used in the study by Young et al. (2012). Young et al. (2012) measured protease activity to be $1,865 \mathrm{U}$ of activity/mg of solids, where $1 \mathrm{U}$ produced a change in absorbency at $280 \mathrm{~nm}\left(\Delta \mathrm{A}_{280 \mathrm{~nm}}\right)$ of $0.001 / \mathrm{min}$ at $\mathrm{pH} 3.0$ and $50^{\circ} \mathrm{C}$, measured as TCAsoluble products using hemoglobin as a substrate. There were no detectable carbohydrase activities. Treatments were applied with separate spray bottles to the piles of forage while mixing. After application, approximately $500 \mathrm{~g}$ of chopped forage from each pile was packed into triplicate nylon-polyethylene standard barrier microlayered pouches (3.5-mil thickness, $15.2 \times 30.5 \mathrm{~cm}$; Doug Care Equipment Inc., Springville, CA) for each treatment and replicated pile, vacuumed to remove air, and heat sealed using an external clamp vacuum machine (Fast-Vac; distributed by Doug Care Equipment Inc.). Bags were stored in a temperature-controlled laboratory between 21 and $23^{\circ} \mathrm{C}$ and ensiled for 45,90 , and $150 \mathrm{~d}$. At each ensiling point, 5 replicate bag silos were opened for each treatment for sample workup. Freshly treated samples from each replicated pile were collected and immediately frozen $\left(-20^{\circ} \mathrm{C}\right)$ and represented $\mathrm{d}-0$ samples.

\section{Chemical Analysis}

Water extracts were prepared by combining $25 \mathrm{~g}$ of fresh forage or silage with $225 \mathrm{~mL}$ of sterile quarterstrength Ringer solution (Oxoid BR0052G; Oxoid Ltd., Cambridge, UK) and homogenizing the mixture for 1 min on a medium setting in a Proctor-Silex 57171 blender (Hamilton Beach/Proctor-Silex Inc., Washington, NC). A portion of the homogenate was filtered through Whatman 54 filter paper (Whatman Ltd., Florham, NJ) and $10 \mathrm{~mL}$ was acidified with 3 drops of $50 \%$ $\mathrm{H}_{2} \mathrm{SO}_{4}$ to reduce the $\mathrm{pH}$ of the extract to $<2.0$, and the water extract was frozen $\left(-20^{\circ} \mathrm{C}\right)$ until further analysis. Water extracts were analyzed for $\mathrm{NH}_{3}-\mathrm{N}$ (Okuda et al., 1965) and water-soluble carbohydrates (WSC; Nelson, 1944). Water extracts from silages were also analyzed for lactic and acetic acids and ethanol by HPLC (Muck 
and Dickerson, 1988). A portion of the unacidified water extracts was used immediately for enumeration of lactic acid bacteria (LAB) by pour-plating on de Man, Rogosa, and Sharpe (MRS) agar (Oxoid CM361; Oxoid Ltd.). Yeasts and molds were enumerated using malt extract agar (Oxoid CM0059; Oxoid Ltd.). Plates were incubated aerobically at $32^{\circ} \mathrm{C}$ for 48 to $72 \mathrm{~h}$.

Fresh forages and silages were analyzed for DM content by drying representative samples in a forcedair oven at $60^{\circ} \mathrm{C}$ for $48 \mathrm{~h}$. The following assays were conducted at Cumberland Valley Analytical Services (Maugansville, MD). A portion of each dried sample was ground through a 1-mm screen using a Udy Cyclone Sample Mill (Udy Corp., Fort Collins, CO). Total $\mathrm{N}$ was determined by combustion of the sample (Leco CNS 2000 Analyzer; Leco Corp., St. Joseph, MI) and $\mathrm{CP}$ was calculated by multiplying the resulting total $\mathrm{N}$ by 6.25 . The amount of soluble protein (as $\%$ of CP; Sol-P) was also determined on these 3-mm ground samples according to methodology described by Krishnamoorthy et al. (1982). The starch content of each sample was determined and corrected for free glucose according to the methodology described by Hall (2009).

\section{In Vitro Starch Digestion}

In vitro ruminal starch digestibility $(7 \mathrm{~h})$ was determined (Tilley and Terry, 1963) on samples ground through a Wiley Mill (Thomas Scientific, Swedesboro, $\mathrm{NJ}$ ) to pass through a 3 -mm screen. In vitro digestions were conducted on 3 separate days and in duplicate for all samples. Ruminal fluid was pooled from 3 lactating cows with rumen fistula that were fed a standard diet comprising $25 \%$ corn silage, $25 \%$ alfalfa haylage, and $50 \%$ concentrate (DM basis).

\section{Statistical Analysis}

The data were analyzed as a $2 \times 3 \times 4$ factorial arrangement of treatments. Main effects in the model were DM at harvest, dose of protease, days of ensiling, their interactions, and residual error. Data were analyzed using the Fit Model procedure of JMP (SAS Institute Inc., Cary, NC) and differences were reported as significant when $P \leq 0.05$. Means were separated by the Tukey test $(P \leq 0.05$; Snedecor and Cochran, 1980).

\section{RESULTS}

The chemical composition of fresh forages and silages is shown in Table 1. Fibrous fractions in forages (ADF and NDF) were not determined in this study, as treat- ment with proteases did not affect their concentrations in previous studies (Young et al., 2012; Windle et al., 2013). Corn plants at the early harvest were lower in DM content $(30.69 \%)$ than corn plants harvested later $(40.33 \%$ DM). No interactions existed between harvest $\mathrm{DM} \times$ dose of protease or among harvest $\mathrm{DM} \times$ dose of protease $\times$ day of ensiling for $\mathrm{DM}, \mathrm{CP}$, Sol-P, $\mathrm{NH}_{3}-\mathrm{N}$, starch, and WSC.

Harvest DM $\times$ day of ensiling interactions were observed for concentrations of CP, starch, and WSC. The concentration of $\mathrm{CP}$ was higher in $\mathrm{LT}$ versus ER corn and remained constant with days of ensiling for both maturities, with the exception of a decrease in ER silage at $\mathrm{d} 150$. The concentrations of $\mathrm{NH}_{3}-\mathrm{N}$ were similar among all treatments in fresh forage and increased with days of ensiling to an equal extent for ER versus LT silages through $90 \mathrm{~d}$ of ensiling. After $150 \mathrm{~d}$ of ensiling, ER silages had lower concentrations of $\mathrm{NH}_{3}-\mathrm{N}$ than did LT silages. The concentration of WSC was higher in LT than ER samples for fresh forage, and was lower in ER than LT samples on d 45 and 90 but similar on d 150 .

Interactions also existed between dose of protease $\times$ days of ensiling for $\mathrm{CP}$, Sol-P, $\mathrm{NH}_{3}-\mathrm{N}$, starch, and WSC. The concentrations of $\mathrm{CP}$ were similar among $\mathrm{CT}, \mathrm{LO}$, and $\mathrm{HI}$ in fresh forage but higher in $\mathrm{HI}$ than in $\mathrm{CT}$ and LO after 90 and $150 \mathrm{~d}$ of ensiling. Concentrations of Sol-P and $\mathrm{NH}_{3}-\mathrm{N}$ increased similarly with days of ensiling for $\mathrm{CT}$ and $\mathrm{LO}$ but were markedly higher for HI compared with these 2 treatments after $45 \mathrm{~d}$ of ensiling. Interactions existed between doses of protease $\times$ day of ensiling and between harvest $\mathrm{DM} \times$ day of ensiling for concentrations of starch. Averaged across harvest times, the concentrations of starch were similar among doses of proteases for fresh forage and silages after 45 and $90 \mathrm{~d}$ of ensiling. However, the concentration of starch was lower in silages treated with the highest dose of protease compared with those silages that were untreated or treated with the low dose of protease at $d$ 150. An interaction also existed between harvest $\mathrm{DM} \times$ day of ensiling for the concentration of starch because whereas its concentration was unchanged with days of ensiling in LO silages, its concentration decreased in $\mathrm{HI}$ silages. Decreases in concentrations of WSC with ensiling were observed and the concentrations were highest for $\mathrm{HI}$ on d 45 and 90.

A 3-way interaction existed among harvest DM $\times$ dose of protease $x$ day of ensiling for IVSD (Figure 1). In fresh forages, treatment with protease had no effect on IVSD, but, on average, it was higher in ER (59\%) than LT (45\%) silage. After $45 \mathrm{~d}$ of ensiling, IVSD remained similar to values observed in fresh forages for $\mathrm{CT}$ and $\mathrm{LO}$ silages but treatment with $\mathrm{HI}$ was equally effective in increasing IVSD for both ER and LT silages. In vitro starch digestibility remained 
Table 1. Chemical composition (\% of DM, unless otherwise stated) of fresh corn plants (after treatment but before ensiling) harvested at different DM contents and treated with various doses of a protease formulation and ensiled for 45, 90, and $150 \mathrm{~d}$, and the effects of the treatments

\begin{tabular}{|c|c|c|c|c|c|c|}
\hline Item & $\mathrm{DM}$ & $\mathrm{CP}$ & $\begin{array}{l}\text { Sol-P, }{ }^{1} \\
\% \text { of CP }\end{array}$ & $\mathrm{NH}_{3}-\mathrm{N}$ & Starch & $\mathrm{WSC}^{2}$ \\
\hline \multicolumn{7}{|l|}{ Treatment $^{3}$} \\
\hline \multicolumn{6}{|l|}{$\mathrm{d} 0$} & \\
\hline $\mathrm{CT}$ & $30.08^{\mathrm{c}}$ & $8.08^{\text {efgh }}$ & $27.56^{\mathrm{k}}$ & $0.036^{\mathrm{hi}}$ & $33.12^{\text {abcde }}$ & $3.28^{\mathrm{bc}}$ \\
\hline $\mathrm{LO}$ & $31.20^{\mathrm{c}}$ & $8.32^{\text {cdefg }}$ & $35.58^{\mathrm{ijk}}$ & $0.040^{\text {ghi }}$ & $37.38^{\mathrm{ab}}$ & $3.49^{\mathrm{b}}$ \\
\hline $\mathrm{HI}$ & $30.78^{\mathrm{c}}$ & $8.36^{\text {cdefg }}$ & $36.66^{\mathrm{hijk}}$ & $0.046^{\mathrm{ghi}}$ & $33.94^{\text {abcde }}$ & $3.13^{\mathrm{bc}}$ \\
\hline \multicolumn{7}{|l|}{ LT } \\
\hline $\mathrm{CT}$ & $39.60^{\mathrm{ab}}$ & $8.92^{\mathrm{abcd}}$ & $34.02^{\mathrm{jk}}$ & $0.024^{\mathrm{i}}$ & $34.62^{\mathrm{abcd}}$ & $8.36^{\mathrm{a}}$ \\
\hline LO & $41.15^{\mathrm{ab}}$ & $8.78^{\text {abcde }}$ & $28.54^{\mathrm{k}}$ & $0.022^{\mathrm{i}}$ & $35.42^{\mathrm{abcd}}$ & $8.23^{\mathrm{a}}$ \\
\hline HI & $40.23^{\mathrm{ab}}$ & $9.12^{\mathrm{ab}}$ & $30.80^{\mathrm{jk}}$ & $0.024^{\mathrm{i}}$ & $33.42^{\text {abcde }}$ & $8.27^{\mathrm{a}}$ \\
\hline \multicolumn{7}{|l|}{ d 45} \\
\hline \multicolumn{7}{|l|}{ ER } \\
\hline $\mathrm{CT}$ & $30.01^{\mathrm{c}}$ & $8.22^{\text {defg }}$ & $40.30^{\text {fghijk }}$ & $0.054^{\text {ghi }}$ & $32.40^{\text {abcdef }}$ & $0.11^{\mathrm{fg}}$ \\
\hline LO & $30.90^{\mathrm{c}}$ & $7.82^{\mathrm{gh}}$ & $38.48^{\text {ghijk }}$ & $0.052^{\text {ghi }}$ & $36.72^{\mathrm{abc}}$ & $0.22^{\text {fg }}$ \\
\hline $\mathrm{HI}$ & $29.94^{\mathrm{c}}$ & $7.94^{\text {fgh }}$ & $70.88^{\mathrm{ab}}$ & $0.102^{\text {cdef }}$ & $33.00^{\text {abcde }}$ & $1.23^{\mathrm{efg}}$ \\
\hline \multicolumn{7}{|l|}{ LT } \\
\hline $\mathrm{CT}$ & $39.85^{\mathrm{ab}}$ & $8.74^{\text {abcde }}$ & $45.30^{\text {efghij }}$ & $0.062^{\text {gh }}$ & $29.32^{\text {defg }}$ & $1.37^{\mathrm{ef}}$ \\
\hline LO & $40.17^{\mathrm{ab}}$ & $8.70^{\text {abcde }}$ & $45.12^{\text {efghij }}$ & $0.056^{\mathrm{ghi}}$ & $31.12^{\text {abcdef }}$ & $1.24^{\mathrm{efg}}$ \\
\hline HI & $38.76^{\mathrm{b}}$ & $8.96^{\text {abcd }}$ & $70.06^{\mathrm{abc}}$ & $0.108^{\mathrm{bcd}}$ & $27.18^{\mathrm{efg}}$ & $2.54^{\text {bcde }}$ \\
\hline \multicolumn{7}{|l|}{ d 90} \\
\hline \multicolumn{7}{|l|}{ ER } \\
\hline $\mathrm{CT}$ & $29.54^{\mathrm{c}}$ & $8.16^{\mathrm{efg}}$ & $49.80^{\text {defghi }}$ & $0.072^{\mathrm{efg}}$ & $33.02^{\text {abcde }}$ & $0.17^{\mathrm{fg}}$ \\
\hline LO & $31.46^{\mathrm{c}}$ & $7.84^{\mathrm{fgh}}$ & $55.92^{\text {bcde }}$ & $0.070^{\text {efgh }}$ & $37.52^{\mathrm{a}}$ & $0.17^{\mathrm{fg}}$ \\
\hline HI & $30.67^{\mathrm{c}}$ & $8.72^{\text {abcde }}$ & $69.24^{\mathrm{abc}}$ & $0.123^{\mathrm{bc}}$ & $31.50^{\text {abcdef }}$ & $1.96^{\text {cde }}$ \\
\hline \multicolumn{7}{|c|}{31.00} \\
\hline $\mathrm{CT}$ & $39.30^{\mathrm{ab}}$ & $8.72^{\text {abcde }}$ & $55.24^{\text {cdef }}$ & $0.075^{\text {defg }}$ & $29.56^{\text {cdefg }}$ & $1.58^{\mathrm{de}}$ \\
\hline LO & $38.86^{\mathrm{ab}}$ & $8.58^{\text {abcdef }}$ & $59.30^{\text {bcde }}$ & $0.068^{\mathrm{fgh}}$ & $30.44^{\text {abcdefg }}$ & $1.77^{\mathrm{de}}$ \\
\hline $\mathrm{HI}$ & $38.33^{\mathrm{ab}}$ & $9.35^{\mathrm{a}}$ & $75.63^{\mathrm{a}}$ & $0.108^{\mathrm{bcd}}$ & $25.14^{\mathrm{g}}$ & $2.68^{\mathrm{bcd}}$ \\
\hline \multicolumn{7}{|l|}{ d 150} \\
\hline \multicolumn{7}{|l|}{ ER } \\
\hline $\mathrm{CT}$ & $30.80^{\mathrm{c}}$ & $7.40^{\mathrm{h}}$ & $53.82^{\operatorname{defg}}$ & $0.104^{\text {cde }}$ & $34.02^{\text {abcde }}$ & $1.23^{\mathrm{efg}}$ \\
\hline $\mathrm{LO}$ & $31.50^{\mathrm{c}}$ & $7.73^{\text {gh }}$ & $64.45^{\text {abcd }}$ & $0.105^{\text {bcde }}$ & $35.00^{\text {abcd }}$ & $0.05^{\mathrm{g}}$ \\
\hline HI & $30.52^{\mathrm{c}}$ & $8.30^{\text {cdefg }}$ & $70.16^{\mathrm{abc}}$ & $0.142^{\mathrm{b}}$ & $28.48^{\text {defg }}$ & $0.10^{\mathrm{fg}}$ \\
\hline \multicolumn{7}{|l|}{ LT } \\
\hline $\mathrm{CT}$ & $42.03^{\mathrm{a}}$ & $8.58^{\text {abcdef }}$ & $51.94^{\text {defgh }}$ & $0.135^{\mathrm{bc}}$ & $30.06^{\text {bcdefg }}$ & $0.07^{\mathrm{g}}$ \\
\hline $\mathrm{LO}$ & $40.46^{\mathrm{ab}}$ & $8.52^{\text {bcdefg }}$ & $59.00^{\text {bcde }}$ & $0.135^{\mathrm{bc}}$ & $30.04^{\text {bcdefg }}$ & $0.05^{\mathrm{g}}$ \\
\hline $\mathrm{HI}$ & $40.03^{\mathrm{ab}}$ & $9.04^{\mathrm{abc}}$ & $70.58^{\mathrm{abc}}$ & $0.200^{\mathrm{a}}$ & $25.28^{\mathrm{fg}}$ & $0.07^{\mathrm{g}}$ \\
\hline SEM & 0.57 & 0.14 & 2.90 & 0.007 & 1.39 & 0.24 \\
\hline \multicolumn{7}{|l|}{ Effect, $P$-value } \\
\hline $\mathrm{DM}^{4}$ & $<0.01$ & $<0.01$ & 0.38 & 0.04 & $<0.01$ & $<0.01$ \\
\hline $\mathrm{PRO}^{5}$ & 0.02 & $<0.01$ & $<0.01$ & $<0.01$ & $<0.01$ & $<0.01$ \\
\hline Time $^{6}$ & $<0.01$ & $<0.01$ & $<0.01$ & $<0.01$ & $<0.01$ & $<0.01$ \\
\hline $\mathrm{DM} \times \mathrm{PRO}$ & 0.06 & 0.87 & 0.27 & 0.83 & 0.13 & 0.84 \\
\hline PRO $\times$ time & 0.30 & $<0.01$ & $<0.01$ & $<0.01$ & 0.01 & $<0.01$ \\
\hline $\mathrm{DM} \times$ time & 0.09 & 0.03 & 0.22 & $<0.01$ & $<0.01$ & $<0.01$ \\
\hline $\mathrm{DM} \times \mathrm{PRO} \times$ time & 0.63 & 0.15 & 0.17 & 0.33 & 0.99 & 0.64 \\
\hline
\end{tabular}

${ }^{\mathrm{a}-\mathrm{k}}$ Means within a column with unlike superscript letters differ $(P<0.01)$.

${ }^{1}$ Soluble protein.

${ }^{2}$ Water-soluble carbohydrates.

${ }^{3} \mathrm{ER}=$ corn plants harvested at $31 \% \mathrm{DM}$; CT $=$ corn plants treated with a $0.1 \mathrm{M}$ phosphate buffer (pH 5.5, 5\% $\mathrm{vol} / \mathrm{wt}$ of fresh forage); $\mathrm{LO}=$ corn plants treated with $0.1 \mathrm{M}$ phosphate buffer $(\mathrm{pH} 5.5,5 \% \mathrm{vol} / \mathrm{wt}$ of fresh forage) with protease, resulting in $20 \mathrm{mg}$ of protease formulation $/ \mathrm{kg}$ of wet forage; $\mathrm{HI}=$ corn plants treated with $0.1 \mathrm{M}$ phosphate buffer ( $\mathrm{pH} 5.5,5 \% \mathrm{vol} /$ wt of fresh forage) with protease, resulting in 2,000 $\mathrm{mg}$ of protease formulation $/ \mathrm{kg}$ of wet forage; LT $=$ corn plants harvested at $40 \% \mathrm{DM}$.

${ }^{4}$ The effect of DM content at harvest.

${ }^{5}$ The effect of dose of protease.

${ }^{6}$ The effect of day of ensiling.

higher in HI silages (for both DM) than in CT silages (both DM) at $90 \mathrm{~d}$ of ensiling. Although IVSD was still numerically higher for silages treated with LO and HI compared with $\mathrm{CT}$ silages after $150 \mathrm{~d}$ of ensiling, no statistical differences existed among treatment protease doses, regardless of DM. 
A)

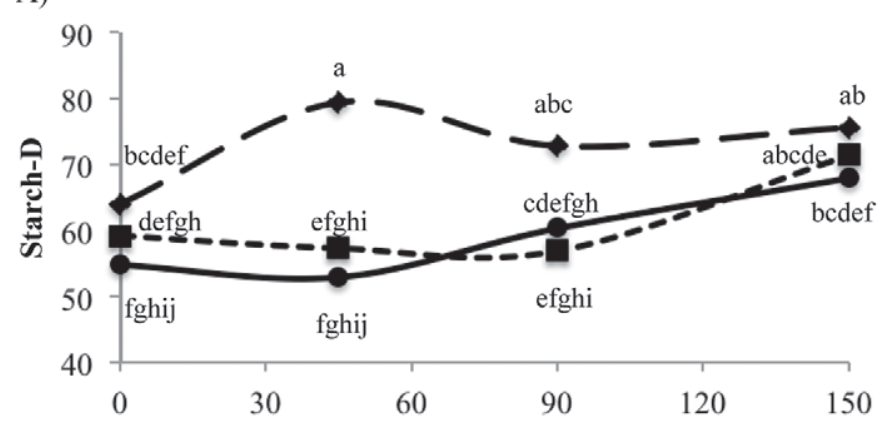

B)

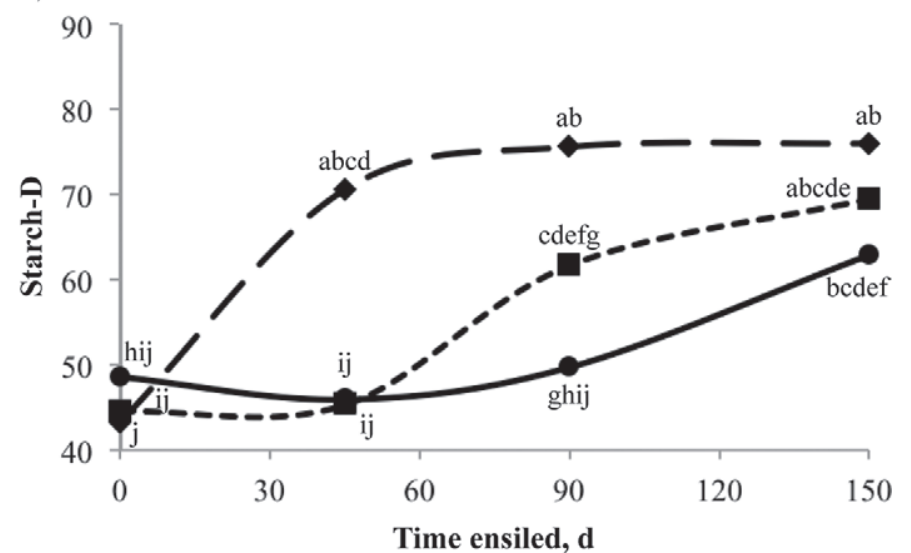

Figure 1. In vitro ruminal starch digestion (Starch-D; $7 \mathrm{~h}, \%$ of starch) of corn silages that were harvested at either $31 \%$ DM (A) or $40 \% \mathrm{DM}(\mathrm{B})$ content and were either untreated $(\bullet)$, treated with 20 $\mathrm{mg}$ of a protease enzyme per kilogram of wet forage weight (ם), or treated with 2,000 $\mathrm{mg}$ of a protease enzyme per kilogram of wet forage weight $(\checkmark)$. Points within both graphs with unlike letters $(\mathrm{a}-\mathrm{j})$ differ $(P<0.05) ;$ SEM $=2.46$. Protease effect: $P<0.01$; day of ensiling effect: $P<0.01$; harvest DM effect: $P<0.01$; protease $\times$ day of ensiling: $P<0.01 ; \mathrm{DM}$ at harvest $\times$ day of ensiling interaction: $P<0.01 ; \mathrm{DM}$ at harvest $\times$ protease interaction: $P=0.88 ; \mathrm{DM}$ at harvest $\times$ protease $\times$ day of ensiling interaction: $P<0.01$.

The fermentation profile and microbial composition of fresh forage and silages are shown in Table 2. The $\mathrm{pH}$ decreased with time of ensiling and was lower in ER than LT forage. Treatment with protease had no effect on forage or silage $\mathrm{pH}$. On average, higher DM silages contained lower concentrations of lactic acid (average of $3.74 \%$ ) than did lower DM silages (average of $4.66 \%$ ). Concentrations of lactic acid were also greater in HI silages (average of 4.93\%) compared with LO (average of $3.95 \%$ ) and CT (average of $3.72 \%$ ) silages when averaged across days of ensiling and harvest DM. The concentrations of acetic acid increased with days of ensiling but were higher in LO than HI silages at $150 \mathrm{~d}$. Averaged across days of ensiling and harvest DM content, silages treated with $\mathrm{HI}$ had higher concentrations of acetic acid (average of $1.23 \%$ ) compared with LO (average of $1.00 \%$ ) and CT (average of 1.06\%) silage.
Three-way interactions existed between harvest DM $\times$ dose of protease $x$ day of ensiling for concentrations of ethanol and numbers of LAB and yeasts. In ER silages, the concentration of ethanol was higher in $\mathrm{HI}$ compared with $\mathrm{CT}$ and LO at 90 and $150 \mathrm{~d}$ of ensiling. In LT silages, no differences were observed in concentrations of ethanol among protease treatments at any day of ensiling. Numbers of LAB increased with days of ensiling in ER for all protease treatments. In contrast, numbers of LAB remained fairly constant among protease treatments between d 0 and 45 in LT, but markedly declined at 90 and $150 \mathrm{~d}$ for all protease treatments. Numbers of yeasts remained fairly constant among protease treatments for LT silages. In ER silages, the numbers of yeasts declined for both $\mathrm{CT}$ and $\mathrm{LO}$ between $\mathrm{d} 0$ and 45 but their numbers remained high through $90 \mathrm{~d}$ for HI. After $150 \mathrm{~d}$ of ensiling, the numbers of yeasts in all ER treatments were below $\log 3 \mathrm{cfu} / \mathrm{g}$.

\section{DISCUSSION}

Because no unexpected effects of harvest DM or changes in chemical composition due to time of ensiling existed, the following discussion will be primarily focused on the effects of the treatment with protease on fermentation and nutritive value.

Proteolysis in the rumen has always been considered excessive and, thus, proteases have generally not been used in ruminant diets to degrade proteins, but they have been used as feed additives (not silage additives) to improve starch digestibility because the prolamin protein matrix that surrounds starch granules within the corn kernel represents a physicochemical barrier to amylolytic rumen microorganisms (Hoffman et al., 2011). This prolamin protein matrix is hydrophobic and, therefore, difficult for rumen microorganisms to digest (Hoffman, et al., 2011). DePeters et al. (2007) reported that using a protease as a feed additive resulted in increased total (in vitro) gas production at 8 and $24 \mathrm{~h}$ uniformly across 4 different hybrids varying in kernel vitreousness. McAllister et al. (1993) reported that a 4 -h preincubation with protease increased rumen microbial fermentation of starch in corn but not barley. This finding may have been due to the fact that the protein-starch matrix was more limiting to digestion in corn than it was in barley. Eun and Beauchemin (2007) incubated ground corn silage in vitro with papain, a proteolytic enzyme, and also reported an increase in the digestibility of starch. In contrast, a protease enzyme from Bacillus licheniformis did not affect ruminal in vitro starch digestibility (Colombatto et al., 2003). Eun and Beauchemin (2008) conducted a meta-analysis of in vitro experiments that used exogenous protease enzymes as feed additives and they reported a positive 
Table 2. The fermentation profile (\% of DM, unless otherwise stated) and microbial composition (cfu/g, wet basis) of fresh corn plants (after treatment but before ensiling) harvested at different DM contents and treated with various doses of a protease formulation and ensiled for 45,90, and $150 \mathrm{~d}$, and the effects of the treatments

\begin{tabular}{|c|c|c|c|c|c|c|}
\hline Item & $\mathrm{pH}$ & $\begin{array}{l}\text { Lactic } \\
\text { acid }\end{array}$ & $\begin{array}{l}\text { Acetic } \\
\text { acid }\end{array}$ & Ethanol & $\begin{array}{c}\mathrm{LAB}^{1}{ }^{1} \\
\log (\mathrm{cfu} / \mathrm{g})\end{array}$ & $\begin{array}{c}\text { Yeasts, } \\
\log (\mathrm{cfu} / \mathrm{g})\end{array}$ \\
\hline \multicolumn{7}{|l|}{ Treatment $^{2}$} \\
\hline \multicolumn{7}{|l|}{$\begin{array}{l}\mathrm{d} 0 \\
\mathrm{ER}\end{array}$} \\
\hline $\mathrm{CT}$ & $5.66^{\mathrm{a}}$ & $\mathrm{ND}^{3}$ & ND & ND & $5.97^{\mathrm{fg}}$ & $5.18^{\mathrm{abc}}$ \\
\hline $\mathrm{LO}$ & $5.77^{\mathrm{a}}$ & ND & ND & ND & $6.03^{\mathrm{f}}$ & $5.45^{\mathrm{abc}}$ \\
\hline $\mathrm{HI}$ & $5.68^{\mathrm{a}}$ & ND & ND & ND & $5.74^{\mathrm{fg}}$ & $5.06^{\mathrm{abc}}$ \\
\hline \multicolumn{7}{|l|}{ LT } \\
\hline $\mathrm{CT}$ & $5.48^{\mathrm{b}}$ & ND & ND & ND & $5.97^{\mathrm{fg}}$ & $5.48^{\mathrm{abc}}$ \\
\hline LO & $5.46^{\mathrm{b}}$ & ND & ND & ND & $6.89^{\mathrm{e}}$ & $5.48^{\mathrm{abc}}$ \\
\hline $\mathrm{HI}$ & $5.49^{\mathrm{b}}$ & ND & ND & ND & $7.08^{\text {de }}$ & $5.23^{\mathrm{abc}}$ \\
\hline \multicolumn{7}{|l|}{ d 45} \\
\hline \multicolumn{7}{|l|}{ ER } \\
\hline $\mathrm{CT}$ & $3.75^{\text {cdef }}$ & $4.30^{\text {bcde }}$ & $0.74^{\mathrm{bc}}$ & $0.42^{\text {ef }}$ & $7.35^{\mathrm{de}}$ & $4.07^{\text {cde }}$ \\
\hline LO & $3.75^{\text {cdef }}$ & $4.86^{\mathrm{bc}}$ & $0.71^{\mathrm{bc}}$ & $0.46^{\text {def }}$ & $7.64^{\text {cde }}$ & $2.70^{\mathrm{ef}}$ \\
\hline $\mathrm{HI}$ & $3.76^{\text {cde }}$ & $6.69^{\mathrm{a}}$ & $1.02^{\mathrm{abc}}$ & $0.75^{\text {def }}$ & $7.80^{\mathrm{bcd}}$ & $6.17^{\mathrm{a}}$ \\
\hline \multicolumn{7}{|l|}{ LT } \\
\hline $\mathrm{CT}$ & $3.72^{\text {cdef }}$ & $3.97^{\text {bcde }}$ & $0.78^{\mathrm{bc}}$ & $0.45^{\mathrm{def}}$ & $7.58^{\mathrm{de}}$ & $4.71^{\mathrm{bc}}$ \\
\hline LO & $3.66^{\text {cdef }}$ & $4.03^{\text {bcde }}$ & $0.68^{\mathrm{c}}$ & $0.39^{\mathrm{f}}$ & $7.64^{\text {cde }}$ & $4.54^{\mathrm{bc}}$ \\
\hline HI & $3.71^{\text {cdef }}$ & $4.32^{\mathrm{bcd}}$ & $1.02^{\mathrm{abc}}$ & $0.53^{\text {def }}$ & $7.66^{\text {cde }}$ & $4.71^{\mathrm{bc}}$ \\
\hline \multicolumn{7}{|l|}{ d 90} \\
\hline \multicolumn{7}{|l|}{ ER } \\
\hline $\mathrm{CT}$ & $3.68^{\text {cdef }}$ & $3.80^{\text {bcde }}$ & $1.07^{\mathrm{abc}}$ & $0.54^{\text {def }}$ & $8.47^{\mathrm{abc}}$ & $2.32^{\mathrm{f}}$ \\
\hline LO & $3.63^{\text {def }}$ & $4.45^{\mathrm{bcd}}$ & $1.00^{\mathrm{abc}}$ & $0.60^{\text {def }}$ & $8.60^{\mathrm{ab}}$ & $3.10^{\text {def }}$ \\
\hline HI & $3.66^{\text {cdef }}$ & $4.90^{\mathrm{abc}}$ & $1.17^{\mathrm{abc}}$ & $2.22^{\mathrm{a}}$ & $7.66^{\text {cde }}$ & $5.79^{\mathrm{ab}}$ \\
\hline \multicolumn{7}{|l|}{ LT } \\
\hline $\mathrm{CT}$ & $3.60^{\mathrm{f}}$ & $2.89^{\mathrm{de}}$ & $1.21^{\mathrm{abc}}$ & $0.88^{\text {def }}$ & $4.71^{\mathrm{h}}$ & $4.55^{\mathrm{bc}}$ \\
\hline LO & $3.61^{\mathrm{ef}}$ & $2.58^{\mathrm{e}}$ & $1.15^{\mathrm{abc}}$ & $0.86^{\text {def }}$ & $4.71^{\mathrm{h}}$ & $4.56^{\mathrm{bc}}$ \\
\hline HI & $3.63^{\mathrm{def}}$ & $3.76^{\text {bcde }}$ & $1.21^{\mathrm{abc}}$ & $0.97^{\mathrm{de}}$ & $5.15^{\mathrm{gh}}$ & $4.96^{\mathrm{abc}}$ \\
\hline \multicolumn{7}{|l|}{ d 150} \\
\hline \multicolumn{7}{|l|}{ ER } \\
\hline $\mathrm{CT}$ & $3.77^{\mathrm{cd}}$ & $3.84^{\text {bcde }}$ & $1.52^{\mathrm{a}}$ & $0.56^{\mathrm{def}}$ & $8.88^{\mathrm{a}}$ & $2.00^{\mathrm{f}}$ \\
\hline LO & $3.81^{\mathrm{c}}$ & $4.24^{\text {bcde }}$ & $1.53^{\mathrm{a}}$ & $1.05^{\mathrm{cd}}$ & $8.88^{\mathrm{a}}$ & $2.00^{\mathrm{f}}$ \\
\hline HI & $3.75^{\text {cdef }}$ & $5.33^{\mathrm{ab}}$ & $1.53^{\mathrm{a}}$ & $1.95^{\mathrm{ab}}$ & $8.91^{\mathrm{a}}$ & $2.63^{\mathrm{f}}$ \\
\hline \multicolumn{7}{|l|}{ LT } \\
\hline $\mathrm{CT}$ & $3.66^{\text {cdef }}$ & $3.54^{\text {cde }}$ & $1.02^{\mathrm{abc}}$ & $0.93^{\text {def }}$ & $5.52^{\mathrm{fgh}}$ & $4.48^{\mathrm{bcd}}$ \\
\hline LO & $3.67^{\text {cdef }}$ & $3.78^{\text {bcde }}$ & $1.06^{\mathrm{abc}}$ & $0.96^{\text {def }}$ & $5.62^{\mathrm{fg}}$ & $4.25^{\mathrm{cd}}$ \\
\hline HI & $3.68^{\text {cdef }}$ & $4.57^{\mathrm{bcd}}$ & $1.28^{\mathrm{ab}}$ & $1.54^{\mathrm{bc}}$ & $5.26^{\mathrm{fgh}}$ & $4.92^{\mathrm{abc}}$ \\
\hline SEM & 0.03 & 0.33 & 0.11 & 0.11 & 0.16 & 0.27 \\
\hline \multicolumn{7}{|l|}{ Effect, $P$-value } \\
\hline $\mathrm{DM}^{4}$ & $<0.01$ & $<0.01$ & 0.10 & 0.03 & $<0.01$ & $<0.01$ \\
\hline $\mathrm{PRO}^{5}$ & 0.96 & $<0.01$ & 0.02 & $<0.01$ & 0.49 & $<0.01$ \\
\hline Time $^{6}$ & $<0.01$ & $<0.01$ & $<0.01$ & $<0.01$ & $<0.01$ & $<0.01$ \\
\hline $\mathrm{DM} \times \mathrm{PRO}$ & 0.23 & 0.08 & 0.96 & $<0.01$ & 0.13 & $<0.01$ \\
\hline $\mathrm{PRO} \times$ time & 0.46 & 0.95 & 0.66 & $<0.01$ & 0.58 & $<0.01$ \\
\hline $\mathrm{DM} \times$ time & $<0.01$ & 0.11 & $<0.01$ & 0.37 & $<0.01$ & $<0.01$ \\
\hline $\mathrm{DM} \times \mathrm{PRO} \times$ time & 0.42 & 0.17 & 0.86 & $<0.01$ & $<0.01$ & $<0.01$ \\
\hline
\end{tabular}

${ }^{\mathrm{a}-\mathrm{h}}$ Means within a column with unlike superscript letters differ $(P<0.01)$

${ }^{1}$ Lactic acid bacteria.

${ }^{2} \mathrm{ER}=$ corn plants harvested at $31 \% \mathrm{DM}$; $\mathrm{CT}=$ corn plants treated with a $0.1 \mathrm{M}$ phosphate buffer $(\mathrm{pH} 5.5,5 \%$ $\mathrm{vol} / \mathrm{wt}$ of fresh forage); $\mathrm{LO}=$ corn plants treated with $0.1 \mathrm{M}$ phosphate buffer $(\mathrm{pH} 5.5,5 \% \mathrm{vol} / \mathrm{wt}$ of fresh forage) with protease, resulting in $20 \mathrm{mg}$ of protease formulation $/ \mathrm{kg}$ of wet forage; $\mathrm{HI}=$ corn plants treated with $0.1 \mathrm{M}$ phosphate buffer ( $\mathrm{pH} 5.5,5 \% \mathrm{vol} /$ wt of fresh forage) with protease, resulting in 2,000 $\mathrm{mg}$ of protease formulation $/ \mathrm{kg}$ of wet forage; $\mathrm{LT}=$ corn plants harvested at $40 \% \mathrm{DM}$.

${ }^{3} \mathrm{ND}=$ not determined.

${ }^{4}$ The effect of DM content at harvest.

${ }^{5}$ The effect of dose of protease.

${ }^{6}$ The effect of day of ensiling.

linear relationship between in vitro gas production and added protease activity. In the current study and that of Young et al. (2012), we used a novel approach of using a protease as silage additive at the time of ensiling.
This application has not been considered before because proteolysis during the natural ensiling process has always thought to be undesirable and usually excessive. When forages are ensiled, the conversion of true 
protein to NPN occurs naturally by plant proteases (Heron et al., 1986) during wilting and by microbial processes during ensiling (Rooke and Hatfield, 2003). During proteolysis, proteins are degraded to peptides and free amino acids and deamination of amino acids can lead to ammonia in the silo (Rooke and Hatfield, 2003). Hoffman et al. (2011) suggested that natural proteolysis was responsible for changes in the prolaminstarch matrix, resulting in improvements in ruminal starch digestion observed with time of ensiling.

In the current study, although the concentration of starch in fresh forage was not different between ER and LT corn, IVSD was numerically lower in the LT corn; reflective of the fact that this material was in fact more mature and less digestible. Ensiling resulted in increases in Sol-P and $\mathrm{NH}_{3}-\mathrm{N}$ concentrations for all doses of protease at both maturities, but the greatest effect was found in silages treated with the highest level of protease. In contrast, a delay in the increase in IVSD occurred for untreated silage and silage treated with the low level of protease through $90 \mathrm{~d}$ of ensiling, with the exception of LT-LO. A similar delay was observed in some but not all of our studies (Der Bedrosian et al., 2012; M. C. Windle and L. Kung Jr., unpublished data, University of Delaware, Newark). It is unknown what causes the delay in some studies or how often this occurs during the ensiling of corn silages on farm. In contrast, IVSD was markedly higher in HI silage than in untreated silage or LO silage after a short period of ensiling for both maturities. Specifically, IVSD was higher for ER-HI after $45 \mathrm{~d}$ than ER-CT and LT-CT after $150 \mathrm{~d}$ of ensiling. Thus, as in the study of Young et al. (2012), IVSD was greater in corn silage treated with a protease at ensiling than in untreated corn silage after a short period of ensiling.

A key aspect of the acidic protease used in our study was the ability to be highly active even when $\mathrm{pH}$ of the silage mass was relatively low ( $\mathrm{pH}$ of 3.6 to 3.9). Proteases added to feedstuffs before feeding have probably been neutral or alkaline proteases, as described by Colombatto and Beauchemin (2009), and these types of proteases would be less active in corn silage. Adding a protease to forages at ensiling and allowing it considerable time (weeks) to interact with its substrate also increases the probability of its effectiveness relative to treating a feed for only several hours before feeding. In the current study, smaller increases in Sol-P and $\mathrm{NH}_{3}-$ $\mathrm{N}$ concentration were observed in untreated silage and LO silage treated than in $\mathrm{HI}$ silage between d 0 and 45 and these changes were not accompanied by an increase in IVSD for those treatments. Thus, proteolytic activity was either too low to result in changes that would affect IVSD for those treatments or the accumulation of proteolytic processes (Sol-P and $\mathrm{NH}_{3}-\mathrm{N}$ ) could have also represented a breakdown of other proteins (e.g., fraction 1 leaf protein) from the stalk and leaves.

Addition of proteases to feeds just before evaluation of feeding has also been shown to improve digestion of NDF (Colombatto et al., 2003; Colombatto and Beauchemin, 2009). One hypothesis for this finding is that proteases may remove structural proteins in the plant cell wall, resulting in more ready access to cellulose and hemicellulose by rumen microorganisms (Colombatto and Beauchemin, 2009). In our previous experiment, Young et al. (2012) used the same protease as in the current experiment as a silage additive and did not observe any changes in in vitro ruminal fiber digestibility and, thus, it was not measured in the current study. Differences in findings of effects of proteases on fiber digestion could be due to timing of application (feed vs. silage additive) or different substrate specificities and $\mathrm{pH}$ optimums among the tested proteases.

A potentially undesirable outcome of treatment with protease in the current study was the finding that in ER silages, there was more ethanol and higher numbers of yeasts in HI silages, compared with LO and CT. These findings may have been a result of more readily fermentable substrates due to treatment with the high level of protease. Although not measured in the current study, higher numbers of yeasts may be lead to potential problems in aerobic stability and, thus, more research is needed to determine an optimal level of protease that improves ruminal starch digestion in a short period of time without stimulating the growth of yeasts.

\section{CONCLUSIONS}

The data from this study supports the previous findings from our group that adding an exogenous acid protease to whole-plant corn at the time of ensiling may be a way to improve the potential ruminal starch digestibility of corn silage after a relatively short time of ensiling. Specifically, treating whole-plant corn at harvest with a high level of an experimental exogenous protease resulted in increased proteolysis and improved IVSD compared with untreated corn silage or silage treated with a low level of protease. In general, the effect was similar in early versus late-harvested forage. These findings suggest that corn could be harvested at an advanced stage of maturity to obtain high yields of total DM and starch but still have relatively high ruminal starch digestibility if treated with a protease at the time of ensiling. However, producers will still have to consider the other challenges that accompany the harvesting of mature corn silage, which include more difficulty in obtaining a high pack density, a higher propensity for poor aerobic stability, and the need for adequate kernel processing. Further studies are needed 
to determine if an economic dose of protease can be established.

\section{ACKNOWLEDGMENTS}

This study was partially funded by AB Vista (Marlborough, UK). The authors thank Caitlyn Merrill (University of Delaware, Newark) for her assistance throughout the study. We acknowledge the assistance of the visiting scholars Mariele Agarussi (University of Viçosa, Viçosa, Brazil) and Lilian Rosa (University of Viçosa). We also thank Scott Hopkins and the farm crew at the University of Delaware for the planting and harvesting of corn.

\section{REFERENCES}

Colombatto, D., and K. A. Beauchemin. 2009. A protease additive increases fermentation of alfalfa diets by mixed ruminal microorganisms in vitro. J. Anim. Sci. 87:1097-1105.

Colombatto, D., D. P. Morgavi, A. F. Furtado, and K. A. Beauchemin. 2003. Screening of exogenous enzymes for ruminant diets: Relationship between biochemical characteristics and in vitro ruminal degradation. J. Anim. Sci. 81:2628-2638.

DePeters, E. J., G. Getachew, J. G. Fadel, L. Corona, and R. A. Zinn. 2007. Influence of corn hybrid, protease and methods of processing on in vitro gas production. Anim. Feed Sci. Technol. 135:157-175.

Der Bedrosian, M. C., K. E. Nestor Jr., and L. Kung Jr. 2012. The effects of hybrid, maturity, and length of storage on the composition and nutritive value of corn silage. J. Dairy Sci. 95:5115-5126.

Ebling, T. L., and L. Kung Jr. 2004. A comparison of processed conventional corn silage to unprocessed and processed brown midrib corn silage on intake, digestion, and milk production by dairy cows. J. Dairy Sci. 87:2519-2526.

Eun, J.-S., and K. A. Beauchemin. 2005. Effects of a proteolytic feed enzyme on intake, digestion, ruminal fermentation, and milk production. J. Dairy Sci. 88:2140-2153.

Eun, J.-S., and K. A. Beauchemin. 2007. Enhancing in vitro degradation of alfalfa hay and corn silage using feed enzymes. J. Dairy Sci. 90:2839-2851.

Eun, J.-S., and K. A. Beauchemin. 2008. Relationship between enzymatic activities and in vitro degradation of alfalfa hay and corn silage. Anim. Feed Sci. Technol. 145:53-67.

Hall, M. B. 2009. Determination of starch, including maltooligosaccharides, in animal feeds: Comparison of methods and a method recommended for AOAC collaborative study. J. AOAC Int. 92:42-49.

Heron, S. J. E., R. A. Edwards, and P. McDonald. 1986. Changes in the nitrogenous components of gamma-irradiated and inoculated ensiled ryegrass. J. Sci. Food Agric. 37:979-985.
Hoffman, P. C., N. M. Esser, R. D. Shaver, W. K. Coblentz, M. P. Scott, A. L. Bodnar, R. J. Schmidt, and R. C. Charley. 2011. Influence of ensiling time and inoculation on alteration of the starchprotein matrix in high-moisture corn. J. Dairy Sci. 94:2465-2474.

Johnson, L. M., J. H. Harrison, D. Davidson, C. Hunt, W. C. Mahanna, and K. Shinners. 2003. Corn silage management: Effects of hybrid, maturity, chop length, and mechanical processing on rate and extent of digestion. J. Dairy Sci. 86:3271-3299.

Johnson, L. M., J. H. Harrison, D. Davidson, J. L. Robutti, M. Swift, W. C. Mahanna, and K. Shinners. 2002. Corn silage management I: Effects of hybrid, maturity and mechanical processing on chemical and physical characteristics. J. Dairy Sci. 85:833-853.

Krishnamoorthy, U., T. V. Muscato, C. J. Sniffen, and P. J. Van Soest. 1982. Nitrogen fractions in selected feedstuffs. J. Dairy Sci. 65:217-225.

McAllister, T. A., R. C. Philippe, L. M. Rode, and K. J. Cheng. 1993. Effect of the protein matrix on the digestion of cereal grains by ruminal microorganisms. J. Anim. Sci. 71:205-212.

Montgomery, M. J., H. A. Fribourg, J. R. Overton, and W. M. Hopper. 1974. Effect of maturity of corn on silage quality and milk production. J. Dairy Sci. 57:698-702.

Muck, R. E., and J. T. Dickerson. 1988. Storage temperature effects on proteolysis in alfalfa silage. Trans. ASAE 31:1005-1009.

Nelson, N. 1944. A photometric adaptation of the Somogyi method for the determination of glucose. J. Biol. Chem. 153:375-380.

Okuda, H., S. Fuji, and Y. Kawashima. 1965. A direct colorimetric method for blood ammonia. Tokushima J. Exp. Med. 12:11-23.

Philippeau, C., and B. Michalet-Doreau. 1998. Influence of genotype and ensiling of corn grain on in situ degradation of starch in the rumen. J. Dairy Sci. 81:2178-2184.

Rooke, J. A., and R. D. Hatfield. 2003. Biochemistry of ensiling. Pages 95-139 in Silage Science and Technology. 42nd ed. D. R. Buxton, R. E. Muck, and J. H. Harrison, ed. Am. Soc. Agron., Madison, WI.

Schwab, E. C., R. D. Shaver, J. G. Lauer, and J. G. Coors. 2003. Estimating silage energy value and milk yield to rank corn hybrids. Anim. Feed Sci. Technol. 109:1-18.

Shaver, R. D., J. Lauer, and K. Shinners. 1999. Here are some tips for corn silage management. University of Wisconsin Extension, Madison. Accessed Aug. 12, 2013. http://www.uwex.edu/ces/dairynutrition/documents/csharv99.pdf.

Snedecor, G. W., and W. G. Cochran. 1980. Statistical Methods. 6th ed. Iowa State Univ. Press, Ames.

Tilley, J. M. A., and R. A. Terry. 1963. A two-stage technique for the in vitro digestion of forage crops. J. Br. Grassl. Soc. 18:104-111.

Vidal, B. C., Jr., K. D. Rausch, M. E. Tumbleson, and V. Singh. 2009. Protease treatment to improve ethanol fermentation in modified dry grind corn processes. Cereal Chem. 86:323-328.

Windle, M., C. Merrill, M. Agarussi, L. Rosa, K. Freedman, C. Asay, N. Walker, and L. Kung Jr. 2013. The effects of an exogenous protease on the fermentation and nutritive value of poorly-processed or well-processed corn silage. J. Dairy Sci. 91(Suppl. 1):313. (Abstr.)

Young, K. M., J. M. Lim, M. C. Der Bedrosian, and L. Kung Jr. 2012. Effect of exogenous protease enzymes on the fermentation and nutritive value of corn silage. J. Dairy Sci. 95:6687-6694. 